\title{
Vitreous opacities after intravitreal triamcinolone injection- a case report
}

\author{
Dhanashree Ratra ${ }^{1 *}$, Vineet Ratra ${ }^{2}$ and Haard Shah ${ }^{1}$
}

\begin{abstract}
Background: We report occurrence of peculiar tiny white thread like vitreous opacities after intravitreal triamcinolone injection. These persisted without any change for over a year. We ascribe them to aggregation of triamcinolone crystals due to the purification methods.

Case presentation: Seven patients (8 eyes) with macular edema developed tiny whitish thread like opacities in the vitreous 2-3 months after undergoing an intravitreal injection of triamcinolone acetonide preparation containing benzyl alcohol as preservative. These opacities persisted unchanged for more than a year. The follow up ranged from 91 to 425 days. Vitreous tap was done in one patient which was negative for infection. All patients initially showed improvement but needed re-treatment for recurrence. One patient developed steroid induced rise in intraocular pressure. Microscopic examination of the drug revealed large string like aggregates of triamcinolone crystals.
\end{abstract}

Conclusions: We hypothesize the possibility of aggregation of triamcinolone crystals into string like structures probably due to the purification methods used during manufacture which led to these thread like opacities in the vitreous.

Keywords: Intravitreal injections, Triamcinolone, Preservative, Vitreous opacities, Macular edema

\section{Background}

Intravitreous triamcinolone acetonide (IVTA) has found widespread application for a variety of posterior segment pathologies which cause macular edema. Its therapeutic efficacy has been well demonstrated in clinical trials [1-3]. And its cost effectiveness has made IVTA a widely used agent. Several drug-related and injection-related complications have been reported ranging from localized subconjunctival hemorrhage at the site of injection to serious sight threatening problems [4]. Triamcinolone acetonide is a long acting steroid which is available as a suspension of crystals in benzyl alcohol. The particulate nature of the drug and the lack of preservative free formulation can give rise to deposits on the retina and in the vitreous cavity. The triamcinolone crystals appear as shiny white deposits in the vitreous and have been reported to last for more than 120 days after injection [5]. We report the occurrence of peculiar small thread like opacities in the vitreous which persisted for over a year after the IVTA injection.

\footnotetext{
* Correspondence: dhanashreeratra@gmail.com

${ }^{1}$ Department of Vitreoretinal Diseases, Medical Research Foundation, Sankara Nethralaya, 41, College Road, Chennai 600006, India

Full list of author information is available at the end of the article
}

\section{Case presentation}

We examined seven patients (8 eyes, one bilateral) out of total 15 patients who had received IVTA injection from September 2015 to September 2016. The study adhered to the tenets of the Helsinki Declaration and was approved by the institutional review board of Medical Research Foundation, Chennai. Written informed consent was obtained from every patient. All patients underwent pre-injection detailed eye examination including best corrected visual acuity, intraocular pressure evaluation and fundus evaluation including macular optical coherence tomography. Triamcinolone acetonide, $0.05 \mathrm{ml}(2 \mathrm{mg})$, (Kenacort, Abbott healthcare private limited, Mumbai, India containing triamcinolone acetonide $40 \mathrm{mg}$ and benzyl alcohol $0.9 \% w / v$ as preservative in aqueous base) was withdrawn from the vial and injected directly intravitreally through the pars plana using a 26 gauge needle. The preservative free triamcinolone was not available to us. One eye received $4 \mathrm{mg}$ IVTA. The injections were performed in the operation theatre with complete aseptic precautions. Before the injection a drop of topical lignocaine and a drop of $5 \%$ betadine was instilled in the eye. After injection betadine eye drops were applied and eye was patched for half an hour. No pre or post injection

C The Author(s). 2018 Open Access This article is distributed under the terms of the Creative Commons Attribution 4.0 International License (http://creativecommons.org/licenses/by/4.0/), which permits unrestricted use, distribution, and reproduction in any medium, provided you give appropriate credit to the original author(s) and the source, provide a link to the Creative Commons license, and indicate if changes were made. The Creative Commons Public Domain Dedication waiver (http://creativecommons.org/publicdomain/zero/1.0/) applies to the data made available in this article, unless otherwise stated. 
antibiotics were used. All the patients were examined the day after and again 3 days later to rule out increased intraocular pressure or any suspected intraocular infection. Thereafter all the patients were examined at monthly interval or depending upon the therapeutic response. As per the routine protocol, all the patients underwent vision check, refraction, slit lamp examination, IOP measurement by applanation tonometer, pupillary dilation followed by retinal evaluation with indirect ophthalmoscopy and an optical coherence tomography scanning.

On indirect ophthalmoscopy, we noticed peculiar tiny, thread like, whitish, mobile opacities in the vitreous, 23 months after the IVTA injection in 8 eyes of 7 patients (Fig. 1) which were different from the powdery, rounded, particulate opacities of freshly injected triamcinolone (Fig. 2). Table 1 lists the details of the patients. Except one, all patients had received multiple prior anti-vascular endothelial growth factor or steroid injections. These opacities were noticed after a single injection of IVTA. Except for 1 patient with vitreous floaters, none had any prior notable vitreous changes. The IVTA injections were given at different time points and did not belong to the same batch of manufacture. There were no common factors linking these patients. Except one patient who developed steroid induced glaucoma, none others had any complications of the IVTA. There was good therapeutic response in all patients with immediate reduction of the macular edema. However, all required retreatment for recurrence of macular edema. They received either IVTA, dexamethasone implant or bevacizumab for further treatment. These thread-like opacities were seen to persist with hardly any change in all patients till the last follow up. The follow up ranged from 91 days till 425 days. The opacities did not resemble infectious endophthalmitis. Also the patients were comfortable with no signs of pain, redness or visual disturbance. We performed vitreous tap for 1 patient, which was negative

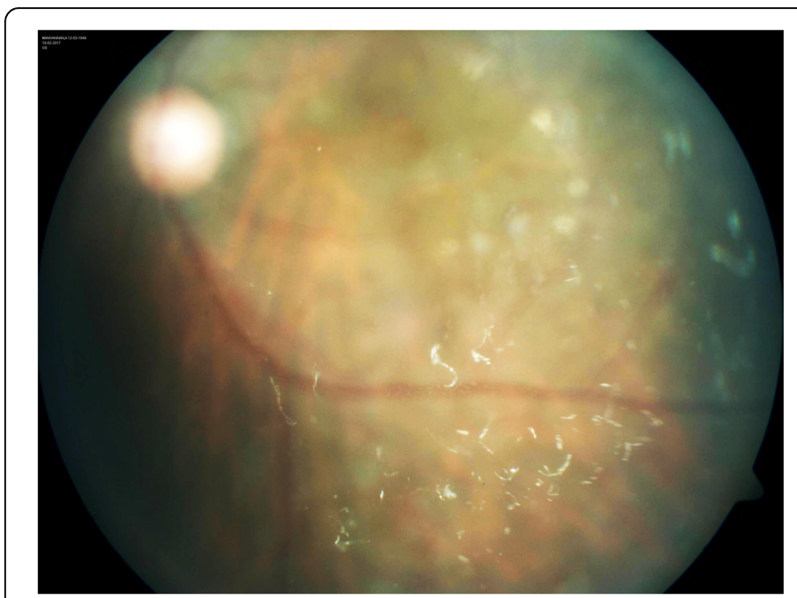

Fig. 1 Tiny white thread like opacities in the vitreous following injection of triamcinolone acetonide

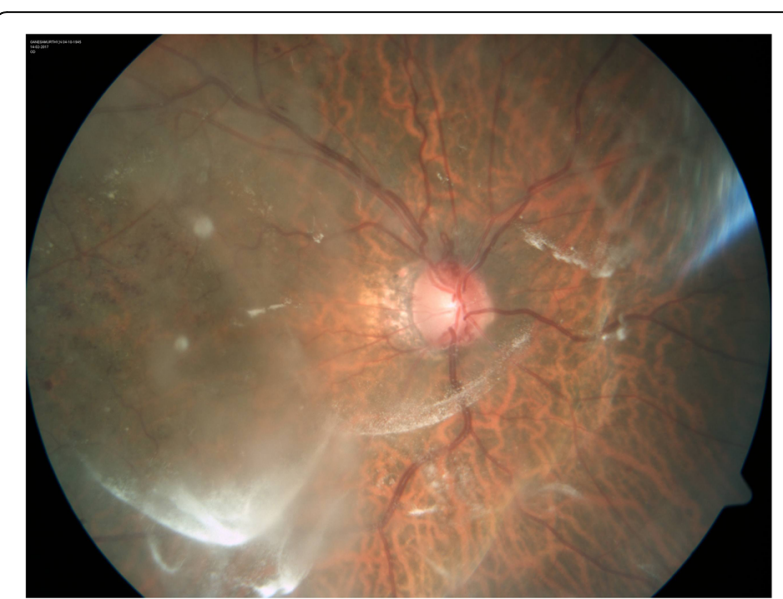

Fig. 2 Round particulate opacities of freshly injected triamcinolone one day after the injection

for any microorganisms or cellular material. The bacterial and fungal cultures were negative. One of the injection vials were also subjected to bacterial and fungal cultures which were negative.

\section{Discussion and conclusions}

Various types of vitreous opacities can occur after IVTA injection. The triamcinolone acetonide, a low water soluble suspension, itself remains in the vitreous as white crystalline deposits. These can cause visual disturbances. On ultrasonography, they appear as clump like, point like, pseudo-membranous or as fine opacities in the subhyaloid space [6]. Triamcinolone is broken down into soluble metabolites 6 betahydroxy triamcinolone acetonide, 21carboxy triamcinolone acetonide, 21carboxy 6beta hydroxy triamcinolone acetonide. These generally clear spontaneously in about 30-60 days.

Both infectious and non-infectious types of endophthalmitis have been reported to occur following IVTA [7]. Bacterial endophthalmitis can occur with vitreous exudates, conjunctival injection, hypopyon and pain. This requires prompt treatment with intravitreal antibiotics. Often times the crystals of triamcinolone can migrate to the anterior chamber giving an appearance of a hypopyon [8].

An endophthalmitis-like reaction also has been reported following IVTA, wherein dense vitreous haze was seen occluding the vision but without the signs of classic infectious endophthalmitis [9]. This haze was seen to clear spontaneously over a few days. The reason for this was not clear but was thought to be due to spraying of the steroid inside the vitreous cavity while forcible injection through the small gauge needle which might have been jammed.

The preservative or the vehicle used for the triamcinolone preparation may also cause a toxic reaction. In animal studies, severe reaction leading to retinal 
Table 1 Demographic details, indications and the number of days the vitreous opacities were seen to be persisting after the triamcinolone acetonide injection in the vitreous

\begin{tabular}{|c|c|c|c|c|c|c|c|c|c|}
\hline Sr No & Age & Sex & Eye & Indication & Lens status & Procedure & Dose & Follow up of vitreous opacities in days & Other complications \\
\hline 1 & 66 & M & OS & DME & Pseudophake & $\begin{array}{l}\mathrm{PE}+\mathrm{IOL}+ \\
\text { IVTA }\end{array}$ & $2 \mathrm{mg}$ & 91 & None \\
\hline 2 & 59 & M & OS & DME & Phakic & IVTA & $4 \mathrm{mg}$ & 218 & $\begin{array}{l}\text { Steroid induced } \\
\text { glaucoma }\end{array}$ \\
\hline 3 & 59 & M & $\mathrm{OD}$ & DME & Phakic & IVTA & $2 \mathrm{mg}$ & 188 & $\begin{array}{l}\text { Steroid induced } \\
\text { glaucoma }\end{array}$ \\
\hline 4 & 43 & $\mathrm{~F}$ & OS & $\begin{array}{l}\text { Pseudophakic- } \\
\text { CME }\end{array}$ & Pseudophake & IVTA & $2 \mathrm{mg}$ & 305 & None \\
\hline 5 & 54 & $\mathrm{~F}$ & OS & $\begin{array}{l}\text { Pseudophakic- } \\
\text { CME }\end{array}$ & Pseudophake & IVTA & $2 \mathrm{mg}$ & 189 & None \\
\hline 6 & 66 & M & OS & DME & Pseudophake & IVTA & $2 \mathrm{mg}$ & 425 & None \\
\hline 7 & 47 & $\mathrm{~F}$ & OS & STBRVO-CME & Pseudophake & IVTA & $2 \mathrm{mg}$ & 216 & None \\
\hline 8 & 68 & M & OS & DME & Pseudophake & IVTA & $2 \mathrm{mg}$ & 344 & None \\
\hline
\end{tabular}

$O D$ right eye, $O S$ left eye, DME diabetic macular edema, $C M E$ cystoid macular edema, STBRVO superotemporal branch vein occlusion, $P E$ phacoemulsification, $I O L$ intraocular lens, IVTA intravitreal triamcinolone acetonide

necrosis has been seen due to the preservatives in various preparations of depot steroids [10]. In vitro studies have shown toxic effects of benzyl alcohol on human retinal pigment epithelial cells [11]. It is recommended to use the preservative free formulation or minimize the amount of preservative in the injection by keeping the injection standing for half an hour after it has been withdrawn in the syringe and then use only the sedimented crystals after discarding the supernatant fluid containing the preservative.

Silicone oil droplets have also been seen after an intravitreal injection. In the SCORE study [11], 33\% of eyes treated with $1 \mathrm{mg}$ of triamcinolone and $12 \%$ of eyes treated with $4 \mathrm{mg}$ of triamcinolone had silicone oil droplets. However, this was due to the use of syringes with staked on needles. The problem disappeared following the change to syringes with luer lock needles.

Till now, there are no reports of such thread like tiny opacities as seen in our case series. A vitreous tap in one patient was negative and ruled out infection. Also, the fact that these patients were comfortable and in fact reported visual improvement with no change whatsoever in the number or appearance of these opacities, rule out the possibility of infection.

When we examined the drug under the microscope it revealed string like aggregates of the triamcinolone crystals (Fig. 3). The different methods used in the preparation of the triamcinolone can affect its crystal size, concentration and distribution. Kleinman et al. [12] conducted particle characterization analyses on different formulations of TA. They found variable crystals size and aggregation in different formulations. Szurman et al. [13] also noted that during the purification process, the crystal size and aggregation tended to differ with different filter parameters such as pore size and filter diameter. However, such string like aggregates have not been reported so far. The size of the aggregates determines whether the crystals will disperse in vitreous or gravitate down [14]. The number and size of the triamcinolone crystal aggregates have also been shown to be correlated with cytotoxicity, with large conglomerates being more cytotoxic [15]. For standardized uniformity, post-purification quality controls have been suggested.

In conclusion, seven patients are reported with development of tiny thread like vitreous opacities after an intravitreal injection of triamcinolone preparation with preservative. These opacities seem to be harmless, causing no visual disturbance or any other symptoms. However, they were seen to persist without any change for over a year.

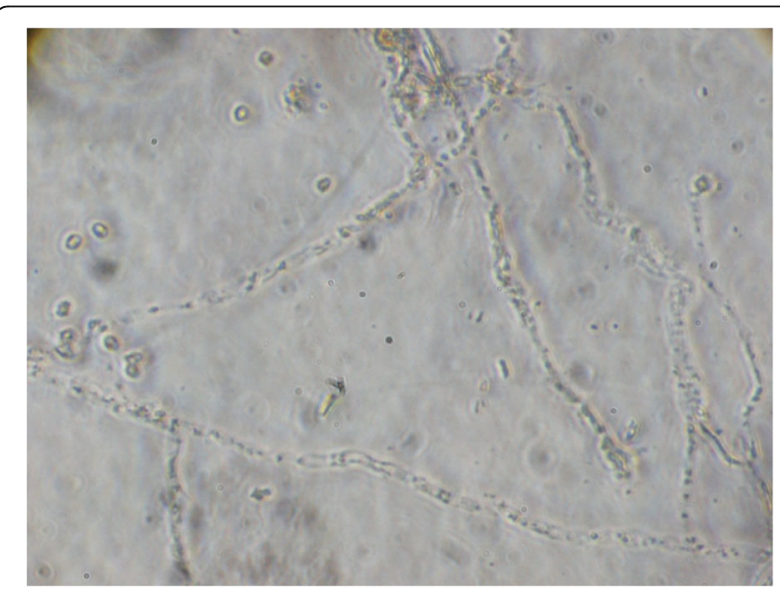

Fig. 3 Photomicrograph of the drug showing thread like aggregates of the triamcinolone crystals 


\section{Availability of data and materials}

The data reported in the article can be found in the table which is included as part of the manuscript.

\section{Authors' contributions}

DR, VR have contributed towards concept and design of the manuscript, analysis and interpretation of data, revising the manuscript critically. HS has contributed towards acquisition and analysis of data, drafting of the manuscript and revising it. All authors have read and approved the final manuscript.

\section{Ethics approval and consent to participate}

The institutional review board of Medical Research Foundation approved the study and written informed consent was obtained from all participants.

\section{Consent for publication}

Written informed consent was obtained from every patient for publication of this case report and any accompanying images. All copies of the written consent are available for review by the Editor of this journal.

\section{Competing interests}

DR has received research grant from Novartis Healthcare for another study. None of the other authors have any competing interests to report.

\section{Publisher's Note}

Springer Nature remains neutral with regard to jurisdictional claims in published maps and institutional affiliations.

\section{Author details}

'Department of Vitreoretinal Diseases, Medical Research Foundation, Sankara Nethralaya, 41, College Road, Chennai 600006, India. ${ }^{2}$ Department of Comprehensive Ophthalmology, Medical Research Foundation, Sankara Nethralaya, 41, College Road, Chennai 600006, India.

Received: 2 September 2017 Accepted: 11 June 2018

Published online: 20 June 2018

\section{References}

1. Zhang XL, Chen J, Zhang RJ, Wang WJ, Zhou Q, Qin XY. Intravitreal triamcinolone versus intravitreal bevacizumab for diabetic macular edema: a meta-analysis. Int J Ophthalmol. 2013;6(4):546-52.

2. Elman MJ, Bressler NM, Qin H, Beck RW, Ferris FL 3rd, Friedman SM, Glassman AR, Scott IU, Stockdale CR, Sun JK, Diabetic Retinopathy Clinical Research Network. Expanded 2-year follow-up of ranibizumab plus prompt or deferred laser or triamcinolone plus prompt laser for diabetic macular edema. Ophthalmology. 2011;118(4):609-14.

3. Diabetic Retinopathy Clinical Research Network. A randomized trial comparing intravitreal triamcinolone acetonide and focal/grid photocoagulation for diabetic macular edema. Ophthalmology. 2008:115(9):1447-9. 1449.e1-10

4. Jager RD, Aiello LP, Patel SP, Cunningham ET Jr. Risks of intravitreous injection: a comprehensive review. Retina. 2004;24:676-98.

5. Vedantham V, Kolluru C, Ramasamy K. Persistent depot of triamcinolone acetonide after a single intravitreal injection. Indian J Ophthalmol. 2005;53: 65-6.

6. Hosseini H, Anvari-Ardakani HR, Karanjam MA, Farvardin M, Nowroozizadeh S. Ultrasonographic pictures of intravitreal triamcinolone acetonide. Eur J Ophthalmol. 2009;19(2):263-7.

7. Nelson ML, Tennant MT, Sivalingam A, Regillo CD, Belmont JB, Martidis A. Infectious and presumed non-infectious endophthalmitis after intravitreal triamcinolone acetonide injection. Retina. 2003;23(5):686-91.

8. Moshfeghi AA, Scott IU, Flynn HW Jr, Puliafito CA. Pseudohypopyon after intravitreal triamcinolone acetonide injection for cystoid macular edema. Am J Ophthalmol. 2004;138(3):489-92.

9. Sutter FKP, Gillies MC. Pseudo-endophthalmitis after intravitreal injection of triamcinolone. Br J Ophthalmol. 2003;87(8):972-4.

10. Hida T, Chandler D, Arena JE, Machemer R. Experimental and clinical observations of the intraocular toxicity of commercial corticosteroid preparations. Am J Ophthalmol. 1986;101(2):190-5.

11. Scott IU, Ip MS, VanVeldhuisen PC, Oden NL, Blodi BA, Fisher M, Chan CK, Gonzalez VH, Singerman LJ, Tolentino M. SCORE study research group a randomized trial comparing the efficacy and safety of intravitreal triamcinolone with standard care to treat vision loss associated with macular edema secondary to branch retinal vein occlusion: the standard care vs corticosteroid for retinal vein occlusion (SCORE) study report 6 . Arch Ophthalmol. 2009;127(9):1115-28.

12. Kleinman ME, Westhouse SJ, Ambati J, Pearson PA, Halperin LS. Triamcinolone crystal size. Ophthalmology. 2010;117(8):1654.

13. Szurman P, Kaczmarek R, Jaissle GB, Grisanti S, Lüke M, Spitzer MS, Heide PE, Bartz-Schmidt KU. Influence of different purification techniques on triamcinolone yield and particle size spectrum. Graefes Arch Clin Exp Ophthalmol. 2007;245(5):689-96.

14. Moshfeghi AA, Nugent AK, Nomoto H, Sanislo SR, Kitchens JW, Moshfeghi DM. Triamcinolone acetonide preparations: impact of crystal size on in vitro behavior. Retina. 2009;29(5):689-98.

15. Spitzer MS, Mlynczak T, Schultheiss M, Rinker K, Yoeruek E, Petermeier K Januschowski K, Szurman P. Preservative-free triamcinolone acetonide injectable suspension versus "traditional" triamcinolone preparations: impact of aggregate size on retinal biocompatibility. Retina. 2011;31(10):2050-7.

\section{Ready to submit your research? Choose BMC and benefit from:}

- fast, convenient online submission

- thorough peer review by experienced researchers in your field

- rapid publication on acceptance

- support for research data, including large and complex data types

- gold Open Access which fosters wider collaboration and increased citations

- maximum visibility for your research: over $100 \mathrm{M}$ website views per year

At BMC, research is always in progress.

Learn more biomedcentral.com/submissions 